\title{
Feminism, masculinities and emotional politics in the late twentieth century
}

Feminism posed powerful political and emotional challenges to progressive men in the 1970s and 1980s. This article investigates politically and personally motivated attempts to 'feel differently' by men in Britain who identified as 'anti-sexist' and aligned themselves with the Women's Liberation Movement. This rescripting of emotions was a central way in which both men and women felt that gender change might be achieved. This article charts the possibilities and limits of attempts by men to find new ways of expressing their feelings. I discuss two sites of changing emotions - consciousness-raising and childcare - and reflect on the complex emotional impact on men of the concept of 'the male gaze' revealed in oral histories. Fine-grained readings of emotions of guilt and shame are needed to understand men's responses to feminism. This article explores how historians might use oral history to capture affect that is expressed somatically, with a particular focus on the emotional lexicon of eye contact and gaze. It concludes with reflections on the extent to which feelings can be consciously changed by individuals or movements.

Keywords: history of emotions, guilt, shame, women's liberation, anti-sexist

Word count: 11984

Lucy Delap

University of Cambridge

Murray Edwards College, Huntingdon Road, Cambridge CB3 0DF

01223762277

Lmd11@cam.ac.uk

Biographical note

Lucy Delap is a lecturer in modern British history at the University of Cambridge, and Fellow of Murray Edwards College. She works on the history of child sexual abuse, and is Deputy Director of History \& Policy [www.historyandpolicy.org]. She has published widely on the history of feminism, gender, labour and religion, including the prize-winning The Feminist Avant-Garde: Transatlantic Encounters of the early twentieth century in 2007, and Knowing Their Place: Domestic Service in Twentieth Century Britain in 2011.

In 1983, feminist activist Lucy Goodison wrote in Spare Rib of the overwhelming intensity of falling in love, its 'laser-like cutting quality'. Though such powerful emotions as love could be bewildering, she called on feminists to '[own] our own power' in emotional terms, and embrace 'a deep-rooted lust for all of life.' Goodison was not alone in her association between feminism and emotional reorientation; for many within the women's movement, changing how they felt about themselves and other women was an important additional project to challenging men and oppressive socio-political structures. Love and joy 
could be redirected from conventional, often heterosexual, encounters in 'nuclear' families, and reworked in relationships with women. Emotions of self-loathing or envy might be transformed into self-love, or anger at men and patriarchal power: 'In our society women are not able to own their own chaotic experiences such as individual feelings of physical vulnerability, anger, rage, fear of violence, hate. ${ }^{2}$ Deep excitement was evident over the feminist project of feeling differently, even though in practice, sisterhood was not always emotionally straightforward. ${ }^{3}$

The emotional transformation sparked by feminism was not, however, limited to women. Lucy Goodison's partner, Paul Morrison, described feeling 'a lot of confusion, or guilt' about how he should respond to feminism. He found joining a men's group from around 1973 'incredibly exciting and incredibly revelatory'. It enabled Morrison to challenge habits learnt from his father, who, he recalled, had 'never talked about his feelings, never told us he loved us, $[\ldots]$ he was a closed book in many ways, and when we as men started talking together, it was fantastically exciting, you know, it was fantastically exciting.' ${ }^{4}$ Another group of men wrote of their feelings after attending a men's workshop in 1974: 'We went to a pub, feeling like re-united lovers. We hugged each other, we touched each other, we talked as if we had known each other in the womb. ${ }^{5}$ Participants in a Brighton-based men's group reflected in 1979 on their powerful emotions on coming into contact with feminism. Owen Davies wrote 'I felt very affected by feminist ideology. I remember feeling almost incoherent with excitement at the first [men's group] meeting, just with the joy and relief of being able to let it all out. ${ }^{6}$

These comments were characteristic of the power of emotional release and excitement that fuelled the involvement of many participants in the men's groups, anti-sexist periodicals and men's childcare initiatives that rapidly developed in the 1970s and 1980s. Feminist women, however, were often sceptical of men's involvement in feminism, as Nicholas Owen has charted. ${ }^{7}$ From the early to mid-1970s, most feminist groups declared themselves womenonly, and other sites of activism such as women's bookshops, women's centres and peace camps followed suit. Activist women felt highly suspicious of the motives of men claiming to be feminists, and defensive of women's intimacy and political autonomy. A perceptive male supporter, David Ratovitsky, noted the tensions that arose in mixed-sex groups: 'Listening is very difficult for many men; we are not used to doing it. In fact, most of us are so unused to listening to women that we don't even realise we're not doing it'. He called for men to 
abandon the political limelight, and 'start cooking meals, being there for the children when they get home from school, changing nappies, washing dishes, reading bed-time stories, doing the washing, the shopping and all the other things women do day in, day out year after year. ${ }^{8}$ Nonetheless, many men sought a more collective engagement with feminism. Significant men's movements developed in Scandinavia, Australia, North America, and Britain. ${ }^{9}$ Thousands of British men sought to transform masculinities and selfhood, in part through deliberate attempts to rework masculine emotional expressiveness.

Their efforts were often rooted in earlier experiments with new ways of living. Whether prompted by the sexual dissidence of $O z$ magazine and its imitators, the intellectual pursuits of the New Left, or the activism of the revolutionary left, 1960s Britain saw some men flamboyantly or doggedly transgress conventional masculinities. They drew on the social confrontations embraced by youth subcultures, and on what Celia Hughes terms the 'rich eclectic cultures of the extra-parliamentary left'. ${ }^{10}$ Protesting the Vietnam War, psychiatry or nuclear weapons, some young British men found new and intense forms of comradeship, which later flourished in student, claimants and civil rights activism. As Lucy Robinson and Matt Cook have shown, the evolving world of gay sociability and activism in the 1970s and 1980s also motivated a powerful sense of 'new times'.11 But it was not always easy to reconcile these forms of selfhood with the criticisms offered by women's liberationists, who accused men of sexism and the exploitation of women. In their intimate relationships, child-rearing, domestic labour, socialising and performing politics, dissident and activist men registered, and resisted or embraced, feminist goals. This article examines those men for whom feminist critiques resonated, and who sought to change their lives accordingly.

Scholars have been increasingly interested in what living these changes felt like, and how new kinds of subjectivities and solidarities might emerge in the activist landscape. ${ }^{12}$ I trace the ongoing evolution of some men's ambition to live life in a new fashion, as it played out at sites of everyday life. Historians of emotions are commonly faced with methodological challenges in recovering the emotional content of the past, much of which is ephemeral and unrecorded. This is particularly so when working on subjects who were invested in muting or restraining their emotions. As Martin Francis has argued, postwar British working and middle-class heterosexual men were offered powerful incentives to subdue their emotional responses. ${ }^{13}$ In contrast, anti-sexist men of the late twentieth century recorded and scrutinized 
their emotions with care, and regarded the formation of new masculine emotional cultures as a key anti-sexist goal. This political movement thus offers a rich case study for historians of emotions, as an archive of emotional scrutiny. I will draw on a collection of 40 interviews undertaken with anti-sexist men and feminist women between 2011 and 2014, in which they reflect on their activism and personal lives over a period roughly spanning the final four decades of the twentieth century. Participants were selected through their involvement in national and local anti-sexist activism; some were identified by women's liberation movement activists, others were named in anti-sexist publications. This oral history evidence is complemented by examination of the periodicals, memoirs, pamphlets and correspondence produced by the anti-sexist men's movement over the 1970s and 80s. ${ }^{14}$

This sample of men were mostly white, disproportionately well-educated and middle class, and clustered in professions such as teaching, social work and creative industries. A substantial minority were gay or bisexual; others did not identify with any sexual identity. Satirically reported in the mainstream media as wimpish 'new men', anti-sexist men by no means represented majority experiences. ${ }^{15}$ However, their urgently felt need to widen their emotional repertoire and learn to trust other men with their feelings does reflect a wider desire for more expressive intimacies in the late twentieth century. As Claire Langhamer has argued, new expectations of love and emotions led to uncertainty about intimate relations, reflected in the high levels of divorce recorded during the 1970s and 80s. ${ }^{16}$ At the same time, rising unemployment and changing workplaces contributed to a sense of precarity and change in the gender order after $1970 .{ }^{17}$ These sentiments extended well beyond the radical or countercultural critiques influencing anti-sexist men. The middlebrow tabloid newspaper the Daily Express, for example, published a double page spread in 1972 which debated 'the masculine concept of the ideal marriage'. It labelled the idea of the breadwinning man supporting a nuclear family as an 'emotional vice' and 'straitjacket'. If conventional marriage was emotionally unworkable, there was however no consensus about what intimate relationships should replace it. The right-leaning Express rejected what it saw as the Women's Liberation alternative of 'doing away with marriage', though rising rates of cohabitation suggested the public was more open to this option. ${ }^{18}$ Beyond the marital realm, there was a pluralisation of ways of being a man in the 1970s and 1980s. Sean Nixon and Frank Mort argue that representations of masculinity that can be read as queer, 'permissive' and disruptive proliferated across commercial and popular culture. ${ }^{19}$ Anti-sexist men were unusual in drawing direct inspiration from feminism, but their efforts to reformulate 
masculinity partook in a widely shared sense of the unsustainability of conventional masculinity in this period.

In exploring men's responses to feminism, this article pays particular attention to feelings of guilt and shame. The former emotion was widely named as a male response to feminism, and a prompt for men's pro-feminist identification and activism. The latter emotion was very rarely named in the oral history interviews I conducted amongst profeminist men, nor in the contemporary sources of anti-sexist periodicals and social movement ephemera. As a feeling that barely registered in consciousness, it might be termed an 'affect', to indicate its primary, embodied nature, though the divide between emotions and affects cannot be clearly delineated. ${ }^{20}$ Nonetheless, I argue that shame can be identified as a key component of anti-sexist men's responses to feminism, illustrated in a series of anecdotes about anti-sexist men's problems with gaze and eye contact.

Methodologically, this focus on gaze and eye contact provides a case study of how observers might go beyond assessing emotion through the inner states named by (historical) actors, and instead be attentive to affect expressed corporeally. There has recently been a growing interest in how historians might analyse, and historicise, the psyche. ${ }^{21}$ Historians of emotions have deliberately sought to look beyond the normative social scripts of 'emotionology', and to investigate how feelings emerge from and through spaces, styles, bodies and political precepts. ${ }^{22}$ It is clear that affective states - understood as intense inner states that precede consciousness - are complex, and are unlikely to be fully accessible to historians, or indeed to historical actors themselves. Humans frequently offer diverse or discrepant assessments of their own emotions, both in terms of the degree of intensity and the identification of what they are feeling. Our emotional vocabulary is impoverished, and often inadequate to the task of identifying the fluid mix of affect and feelings. If affective states are frequently opaque to their bearers, how can historians hope to recover them? Reading emotions as a bodily idiom, expressed in gestures, demeanour and bodily posture, is one way in which to extend our reading of emotions at a historical distance. Historians of emotions have stressed the significance of the somatic performance of emotional repertoires; emotions have been productively conceptualised in terms of 'emotional practices' ${ }^{23}$ Julie-Marie Strange's study of mourning in early twentieth century working class communities, for example, has suggested that 'linguistic fluency was not necessary, or even desirable, for the expression of loss... Non-verbal signs (mannerisms, intonation, facial expression and silence) 
can convey profound emotion and attachment. ${ }^{24}$ And as Laura Gowing has recently argued, looking at gesture and gaze can be particularly revealing of how gender is performed and power manifested: 'Those with power used physical closeness, touch and eye contact; those with less power lowered their eyes and kept their distance... To look someone in the face was a loaded gesture. ${ }^{25}$ In this article, I deploy sources on gaze to deepen our understanding of how emotions are embodied, and how the physical body is enrolled in historically specific forms of social structures and political aspirations.

\section{Emotional labour and transformation}

Women's Liberation activists produced sophisticated reflections on the relationship between women's emotions and liberation. In contrast, change amongst men was often portrayed as a straightforward result of male feelings of guilt. During my interviews with anti-sexist men, guilt was by far the most commonly discussed emotion. One interviewee, Mark Long, became involved in a Liverpool men's group in 1980, after having attended a national anti-sexist men's conference in the same year. He had been, in his words, 'driven' to take action by his friendship with feminist women. For Long, 'the keynote [of the antisexist men's movement] was one of chronic guilt [laughs] basically, that we were in this kind of oppressor role towards women'. He found it difficult in practice to engage with women's groups - the Liverpool socialist feminist group with whom anti-sexist men met in 1980 was 'quite angry about their position, kind of supportive of the men coming forward to do something, frustrated that they couldn't get of us what they wanted out of all men, erm, and in turn, I think the men who went to those meetings were kind of a bit inhibited and nervous about being destroyed for having popped their head over the parapet. ${ }^{26}$ Nonetheless, in Long's case, guilt was productive; he went on to found the Liverpool-based Creches Against Sexism network, providing crèches staffed by men at events between 1981 and 1985 .

For other men, their politicisation was brought about through reading feminist texts. As a social worker, Paul Smith, also based in Liverpool, had come into contact with feminist colleagues. He regarded himself as middle class, educated, and 'a liberated male' due to his treating women with 'complete respect'. It was thus a personal shock when feminist authors directly challenged him to change. Smith described reading Andrea Dworkin's Woman Hating, Kate Millet's Sexual Politics, and Ingrid Bengis' Combat in the Erogenous Zone, 
which 'sort of blew my mind... I was caught by this feeling of ... great grief that I hadn't been informed correctly about the oppression of women, which turned into guilt and shame, terrible guilt and shame when I read this really angry account of what had happened to women over the years.' He continued to read radical feminism 'voraciously', joined a men's group, and brought an anti-sexist dimension to his involvement with the radical leftlibertarian group Big Flame. ${ }^{27}$

In addition to inspiring guilt amongst men, the Women's Liberation Movement also offered a more specific critique of the emotional status quo, and in particular, men's emotional dependency on women. The concept of 'emotional labour' had been developed in 1983 by sociologist Arlie Hohschild to describe the demanding nature of service sector work, with its compulsory smiles and good humour towards customers. The women's movement had long been alert to this kind of labour - Spare Rib in 1976 had highlighted the strain on female shop assistants, expected to smile all day 'even if we had no customers'. ${ }^{28}$ Women were similarly aware of the unequal emotional economy of their intimate relationships with men. The bantering, competitive and often homophobic relations between men that pervaded associational life and workplaces of the middle twentieth century, it was argued, had produced deep male emotional dysfunction. Unable to share their emotions with other men, men turned to women for emotional sustenance and ego-massaging. Feminists demanded that men start to perform this emotional labour for themselves. Feminist writer Jan Bradshaw noted: 'men have never really looked into themselves or related to each other deeply.' When her partner joined a men's group, she looked forward to 'the prospect of being relieved of the choice of either shouldering all his emotional needs myself, or having him go off and lay it on some other woman. ${ }^{29}$ Lucy Goodison and Sheila Ernst's 1981 women's therapy manual pithily noted, 'men will have to become their own women.' 30

Men who were responsive to feminist critiques were aware that they needed to recalibrate their relationships with other men. The Islington Men's Group declared in 1974: 'we all of us feel happier and excited by the sense of freedom that comes from beginning to throw off the whole 'masculine' way of being a person - we feel like emotional cripples beginning to walk. ${ }^{31}$ Brighton-based activist Ian Adams reflected before attending a Men Against Sexism national conference in 1975, 'I hope to escape the impersonal, meaningless unemotionalism that I have been taught to exhibit. ${ }^{32}$ Many felt that this was best achieved by (temporarily) meeting in all-male groups. As Paul Smith carefully noted, 'I'd been led to 
believe was that it was sexist for men to rely on women for emotional support, and not to look to other men for emotional support, so forming a group where we could support each other emotionally, whatever that meant, was a form of anti-sexist action. ${ }^{33}$ In addition, emotional disclosure and honesty in front of (feminist) women was felt to be too challenging for many men in the short term.

\section{Men's groups, therapy and new masculinities}

The men's movement experimented with various different sites at which the 'new' or anti-sexist man might be realized. Men-only consciousness-raising groups, conferences and workshops were initiated by men across Britain, and their operations were discussed in numerous anti-sexist periodicals and pamphlets. Participants were aware of the scepticism many feminists felt towards this development. In Manchester, a Men Against Sexism collective statement insisted defensively in 1976: 'We are not intending to create yet another all male gang, like the rugby team, muscle-builders association and other groups of men that are closed to women for the purpose of preserving male privilege. But these aren't the only ways for men to relate together. Meeting as men's groups can help us to break thru [sic.] to a new kind of trust and brotherhood. ${ }^{34}$ Many participants had come from socialist and trade union activism, and some continued to be committed to collective mobilisation rather than what a Big Flame activist dismissed as men who 'push off to have their kids, lick their wounds and do their horoscopes. ${ }^{35}$ Les Garner, a member of a Camden men's group and later a historian of feminism, was initially sceptical. He argued in 1977 that a men's 'movement must organise where the majority of men are - and not sit around in cosy discussion groups on Sunday afternoon in Dalston or Tuesday nights in Hampstead. Obviously this would involve, for example, raising the issue of sexism at work and, in particular, within your own Union. ${ }^{36}$ Others, however, sought to turn the workerism of the Left, and rejected 'the abstractness and theoretical expertise which in our pasts as male socialists has tended to be central to our identities [...] and to acknowledge people's personal lives as central to their being [...] The left is often not a place to feel good in. ${ }^{37}$

In seeking more positive emotions, men's consciousness raising groups were strongly influenced by widespread experiments in grassroots therapeutic initiatives, such as cocounselling, gestalt therapy and primal therapy. These initiatives were eclectically inspired by the work of Carl Jung, Wilhelm Reich and other psychotherapists, as well as ecospiritualism, and 'new age' or 'Eastern' religions. They provided an influential infrastructure 
for experiments in peer-to-peer working through of feelings and traumas. ${ }^{38}$ Anti-sexist men sought self-consciously to insert new feelings into their emotional repertoire, in what was often a difficult, challenging process. Danny Cohen, heavily involved in initiatives such as Cash against Sexism and Creches Against Sexism in London in the 1970s and 80s, wrote about being part of 'a mixed group focussing on patriarchy and how to achieve a nonpatriarchal society. We went very deep, and ultimately it became too painful for the group to continue. ${ }^{39}$ Jeff Hearn, a Bradford-based theorist and anti-sexist activist, described a workshop on co-counselling held at a Manchester Men's Movement conference as 'both very, very worrying and very, sort of like, amazing'. ${ }^{40}$

The co-counselling movement provided the most influential framework for anti-sexist men, with its rhetoric of 'interrupting' oppressions and recovering from 'early hurts'. This approach, founded by American Harvey Jackins, was widely practiced in Britain, divided into two strands, Re-evaluation Co-Counselling $[\mathrm{RC}]$ and Co-Counselling International. Both approaches influenced anti-sexist men. In Liverpool, the men's crèche group, consciousness raising group and Co-Counselling groups served overlapping memberships. Mark Long described how influential $\mathrm{RC}$ was for him in overcoming the isolation and numbness he associated with masculinity. He welcomed opportunities to talk through childhood 'hurts', express his feelings through 'discharging' - which might involve tears, laughing, or shaking - and learn to sustain physical contact with other men. Co-Counselling was particularly attractive because it framed itself as a liberation movement rather than a therapeutic community. It was premised on finding pride in aspects of identity - including masculinity. The UK Southern Region RC produced Men's Magazine, edited by Trefor Lloyd. One edition described a workshop in 1981 titled 'Women's Liberation Workshop for Women and Men', in which a participant, Rosie, asserted 'We are all hurt by sexism ... Women's liberation has to be the goal of men and women.' ${ }^{41}$ The workshop included sessions such as one titled 'Pride in my penis'. The embrace of physical contact between men was widely experimented with, both within and beyond the RC community.

These kinds of therapy experiments ran alongside and informed men's groups. They encouraged challenging practices in consciousness raising such as confessions of fears, group massage sessions or examination of penises, in an attempt to break taboos on touching male bodies and being honest about vulnerable feelings. The presence of gay men in the anti-sexist men's movement added to the discomfort of many straight men, for whom overcoming homophobia and trusting gay men as confidantes was challenging. Mark Long found the gay 
men at the national anti-sexist men's conferences intimidating. He confessed that when signing up for his first anti-sexist men's conference, he had feared being politically obliged to become gay. Paul Smith also found emotional intimacy between men complex. At one men's conference, he recalled with discomfort 'there were a lot of men who were hugging each other and kissing each other [...] there was a lot of embarrassment around that as well. You didn't know who you could - who you were supposed to..., and who you weren't ...' Talk of 'political lesbianism' had led Smith, like Long, to feel that feminism might require supportive men to become gay. This however was a productive idea for Smith, and enabled him to come to identify as bisexual. ${ }^{42}$

Men's groups often collectively experienced enormous emotional release and positive feelings by using therapy techniques. A member of the Achilles Heel men's magazine collective, Tom Weld described a men's weekend at the Scottish radical collective Laurieston Hall in 1979:

We had been strangers but we could cry, scream, and share our darkness. Not that this was easy. For most of us it was very hard even to say how we were feeling. To talk about and express our feelings in whatever way about our deepest fears and problems, took a tremendous collective effort. .. Several men just needed to cry; some had not been able to for years. $^{43}$

Prominent anti-sexist activist Keith Motherson wrote of how a men's consciousness raising group session he held at the Ecology Party's Summer Gathering in 1981 was 'followed by an all-male sauna in the sweat lodge [...] Naked bodies, dark, steam, heat, sweat earth, chanting, touch. Magic purification ritual of brotherhood.' 44 Jeff Hearn recalled that his men's group was 'very joyful and very hilarious sometimes, absolutely hilarious'. Nonetheless, like Tom Weld, he dwelt on the extraordinary experience of men publically crying in such groups. He recalled one session where he was 'really, really, going full-pelt for both anger and crying at the same time.' Despite the 30 to 40 intervening years, tears were also sometimes elicited in oral history interviews, and many men commented on what an emotional experience being interviewed was.

The tears of anti-sexist men were both a mark of the trusting, caring spaces that most men's groups aimed to provide - a space in which it was safe for men to cry. ${ }^{45}$ But men's tears were also a response to the troubling, difficult emotional experience of taking on board 
feminist insights. Men's encounters with feminism and feminists were not easy to manage. While some men's groups persisted and provided empowering experiences of male friendship, others were quick to break up in acrimony. Tensions were sometimes exacerbated by the eclectic, DIY nature of the therapeutic experiments. Five Cram, active in Cardiff men's groups in the 1970s and 80s, joined an 'encounter group', which was 'based on whatever they could find, you know, gestalt groups, people would, um, read about something or go and do a workshop and then come back and do it with us. ${ }^{46}$ Some therapy was conducted without a sense of professional safeguarding, and allowed for sexual relationships to develop alongside counselling. One interviewee, John Colvin, talked of his experiments with a late 80 s therapeutic and spiritual group: 'it was very distressing, it was very frightening. It was really scary stuff, took me probably ten years to recover from it.... it was really destabilising as well as healing...' Another talked of his involvement with Primal Therapy, which he described as a 'scary environment' where he 'learnt to shout quite a lot'. He felt that he was 'trying to understand myself and understand my feelings', but these efforts at emotional change left him 'in a delicate mental state' ${ }^{47}$ Consciousness raising and therapy techniques thus proved immensely productive for men's groups, but were sometimes unpredictable and disruptive in their effects.

\section{Children, fathering and Emotions}

For anti-sexist men, caring for children was also prioritized, as a contribution to domestic labour and as a site for emotional transformation. Despite recent scholarship suggesting a transformation in fatherhood towards more commitment and involvement in the postwar decades, many anti-sexist men were still inhibited around children. ${ }^{48}$ Phillip Store noted that his care for his own children was 'awfully mechanical', and dogged by 'fears and tensions' around being a male carer. ${ }^{49}$ Paul Smith cared for the children of his partner in early 1980s Liverpool, and recalled his experiences of 'just pushing Aaron or Aidan around in a push chair, and I'd see these other men as well, you know? During the day, doing the same thing, pushing push chairs [laughs].' The exchanges between male carers were awkward and minimal: 'I'd sort of say, "alright there, alright there." [laugh], and they'd say, "alright". So..."50 Achilles Heel noted in 1980, 'most men remain frightened of the responsibility of young babies. They feel inadequate, clumsy; the [sic] can't bear causing tears - nor do they believe in their own ability to console. ${ }^{51}$ John Taylor, active in men's groups in London in the 1980s, noted his desire for fathering 'to be a full experience for me' 
when his first son was born in 1979. Yet he also noted his feelings of physical awkwardness around caring for his sons 'I couldn't throw myself into it'. In some frustration, one Cambridge activist declared in the Antisexist Men's News: "caring for children is the best kind of consciousness raising I've done. Kick out the talk shops lads, and get into the kitchens and crèches. ${ }^{52}$

Crèches had been characteristic of radical and grassroots political organising, but had often been an obvious afterthought. David Widgery, a medical doctor, cultural critic, and activist within the Trotskyist International Socialists [IS], described an attitude within IS that 'kids were a nuisance.' Crèches at meetings were 'perfunctory, [consisting of] one and a half toys and a floor and no-one would ever particularly want their children to be in them...' He reflected on the radical left as 'mainly childless'. ${ }^{53}$ The male-run crèches provided at National Women's Liberation Movement Conferences in the mid to late 1970s, however, were a sign of the growing commitment to childcare by men involved in men's groups. At the 1977 conference, the crèche hosted around 200 children, including some cared for overnight. The same group of men also ran the crèche for the National Women's Aid conference that year, and published a pamphlet, Please can I stop being a tree soon?, describing their efforts to keep children safe and happy. It was clearly a challenging environment, with elements of chaos, recrimination and lack of practical understanding of children. But the pamphlet also provided valuable resources (menus, registration forms, budgets) and noted the feeling of enjoyment and pleasure, both in the children's company and in forming relationships with other men. Characteristically, this was combined with agonising about what the women at the conference would think about their motives and contribution; one crèche-worker wondered, 'perhaps we do this to get the approval of feminist women for us 'anti-sexist' men in general?'54

The crèche work organized by 'Crèches Against Sexism' groups in Liverpool, London, Cardiff, Newcastle, Leeds, Manchester, Oxford and Bristol gave men a wider set of opportunities to relate to children. In Bristol, a network of 40 men provided childcare at women's events in the early 1980s. In Liverpool, 1983 saw 35 crèches provided by men to a range of community and women's groups. Mark Long noted that he had little contact with children prior to his anti-sexist crèche work, but found that 'working with children, you had plenty of opportunities, who, who were not so limited to hug and embrace children. ${ }^{55}$ 
Many anti-sexist men had been involved in pro-feminist activism in their early twenties, but later went on to have their own families and step families. For some, parenting became the area where they felt a huge and positive change in their social relationships. Paul Morrison had a daughter in 1976 with Lucy Goodison, and published a series of poems titled Pregnant Fatherhood which celebrated fatherhood as a moment of personal consciousness raising. ${ }^{56}$ Paul Atkinson, a founding editor of Achilles Heel whose son was born in 1977, regarded fathering as 'a very core thread in what was going on [...] we had our children and then $[\ldots]$ I think we fathered very... we were very hands on, really... you know... and emotionally very present, with our kids. ${ }^{57}$

Nonetheless, this remained an individual experience rather than a social trend; many anti-sexist men found their relationships with children complex and challenging. For some, this was because their leftist critique of the nuclear family could not be squared with the intense feelings they had for their children. Phil Gross noted his commitment to the collective upbringing of children, but found that "none of this applies to what I feel for Rosie [his daughter]. ${ }^{58}$ Others experimenting with collective living and radical politics found combining personal relationships and children deeply problematic. As Paul Atkinson recalled, couples frequently had not made a 'commitment to having children together, that was part of the problem, that within that culture [...] sexual relations were so bloody fluid, and so unthought, and often so destructive.' For Atkinson, splitting up with his feminist partner 'was incredibly painful... [My son] was only about four when we separated... er... and, er, I went through a really really difficult... time...'. Nonetheless, when he later had a daughter, he consciously drew on his men's movement experiences of emotional 'closeness and openness'.59

Care for children beyond the 'nuclear' family proved particularly complex for gay men. There were few established scripts to follow for gay men who became parents, and many did so with low expectations. Chris Heaume donated sperm to a lesbian couple, and did not expect any further involvement. He only became involved in the care of the resulting twin sons when the children were three, after relationship troubles emerged for the lesbian couple. The resulting arrangement was, for Chris, unexpected, rewarding, but hard to manage, particularly because of the lack of boundary setting by adult carers, and uncertainty about what commitment was expected of him. ${ }^{60}$ From around 1980, Nick Snow, a gay actor and 
housing activist, shared the care of Davie, the child of a feminist friend with whom he lived in a gay and lesbian housing cooperative in Hackney. His offer of care had been motivated by a sense of political obligation, but for Snow, co-parenting 'was the most wonderful opportunity for me, and I just fell in love with [Davie]. ${ }^{61}$ For the child, however, the experience of multiple carers was not positive, and after painful disputes with the various women involved in Davie's care, Snow lost contact with him in the late 1990s. For all their transformative power, relationships with children proved no easy emotional landscape for gay anti-sexist men to negotiate.

Other men found the care of children to be a major cause of disputes with women, particularly over child custody. Andy Barrow raised two sons with a partner in the 1970s, but found that despite his commitments to anti-sexism, becoming a father triggered the behaviour he had rejected in his own father: 'I made some big mistakes and several times I kind of looked at myself and found myself acting out, and not as my father had done but in similar ways - I became very bad tempered...' He was proud of his involvement with the births and care of his sons, but when his relationship with his wife broke down, he went into a bitter custody dispute and eventually lost contact with one son. Another member of a long-lasting men's group in Cambridge, Dan Arras, had managed to negotiate amicable domestic arrangements for the care of his daughter with his ex-wife after their breakup in 1986. But he became outraged at the 'grossly unfair' treatment of fathers by the family courts, and founded a local branch of the national fathers' rights lobby group Families Need Fathers in 1991. Despite its reputation for being anti-women, Arras perceived Families Need Fathers [FNF] to be 'about maintaining a good relationship between the fathers and the children,' and thus to be an extension of his pro-feminist commitments. ${ }^{62}$

For many other men, however, the fathers' rights agenda was not easily integrated with feminism. Divorce and custody disputes became widely discussed in the men's movement by the 1980s, contributing to rifts not only between individual men and women, but more generally between the men's movement and the women's movement. With divorce rates at $22 \%$ in 1970 and rising sharply thereafter, the issue of childcare and custody became significant areas of conflict. ${ }^{63}$ Paul Wolf-Light had become a leading figure in the turn towards positive men's rituals and brotherhood amongst some men's groups in the 1980s. This wing of the men's movement became known as 'mythopoetic' men's politics, though these practices were always a minority affair in the British men's movement. Wolf-Light 
wrote of his own experiences of hostility and humiliation after his relationship with the mother of his children broke up. Many men felt that neither the courts nor their former partners adequately respected their rights to equal parenting. For Wolf-Light, this powerlessness 'demeaned me as a man. [...] To know that a woman had power over me increased that feeling. I experienced the urge to fight or leave rather than maintain a relationship.' Yet he also acknowledged with honesty that 'the fear of ridicule and dismissal by other men played a part. ${ }^{64}$ Like Dan Arras, Wolf-Light insisted that men should stay emotionally connected to their children, and to that end, remain respectful of their partners. Nonetheless, his talk of being demeaned as a man was in a very different register from the pro-feminist debates of the 1970s and early 1980s.

\section{Repudiating Guilt}

Through constructing new repertoires of feeling for men, the anti-sexist men's movement became increasingly divided over the emotion that had seemed primary to being an anti-sexist man: guilt. Achilles Heel $[\mathrm{AH}]$ was the most high profile and professionally produced anti-sexist magazine, performing a similar role to Spare Rib within the women's movement as the public face of the men's movement. Founded in 1978 and published semiregularly until the late 1990s, AH was from the outset critical of the previous 'men's movement', which AH collective members regarded as 'apologetic about being men. ${ }^{65}$ In a similar fashion to earlier activists, AH editors and contributors encouraged men to get more in touch with their feelings; the first issue advised men to explore 'relationships in which the usual suppressed emotions could be let out and explored - anger, competition, jealousy, care and love.' But there was a new sense of boldness about the emotional change envisaged. For the Achilles Heel collective, feminist-inspired guilty feelings should be rejected by men. They called for a shift, 'from men's groups acting defensively and out of guilt at being men to one where the relationships between men were increasingly validated in their own right.' Letters in AH raged against "the guilt and self denial we have been brought up with since birth' ${ }^{66}$ One activist referred to guilt as 'the great mind-warper'. Paul Atkinson recalled that 'I couldn't really identify with men who were... going into some sort of guilty... position, in relation to women, and that was their duty to change their behaviour and stop using certain words and... I mean I remember one guy saying... [laughs] saying that he had taught himself to look to the ground, as he passed women. ${ }^{67}$ 
In 1981, a special issue of the Anti-Sexist Men's Newsletter was devoted to exploring guilt, largely in negative terms. A contributor, Peter Martin, argued:

Men seeking to be allies to women seem to be jerked back by feelings of guilt. This negative emotion serves no useful purpose and leads to actionless introspection. It is, I believe, fundamentally a mechanism to return attention to the 'Guilty' and away from positive action. $^{68}$

Feminist women seemed to agree; one talked of guilt as making men 'either cringing servant or patronising helper' of feminists. Another wrote in to the Anti Sexist Men's Newsletter:

Guilt is USELESS. It's a way of sitting around beating your chests, saying you're sorry, you know you've done wrong, “but please forgive me”. I don't want your apologies, I want to see evidence of some action to change - not just introspective ramblings and learning to cry. Your tears won't change a rapist or help with my little boy... ${ }^{69}$

Feminist objections related to guilt as a paralysing emotion, inhibiting men from more positive change. But many men saw guilt not so much as self-indulgent, but as obscuring more positive masculine emotions. Peter Martin himself recommended that men's groups 'take time each, just to say the words 'I am a Man' again and again and see what feelings come off. ${ }^{70}$

A 1982 article in the periodical Against Sexism Against Patriarchy by Cardiff-based anti-sexist Five Cram critiqued 'this self-castigating guilt and negative thinking [which] is not going to inspire many potential anti-sexist men to become involved. ${ }^{71}$ Instead, he implored the men's movement to concentrate on 'how antisexism benefits men.' This strand of the men's movement was influenced by the more assertive men's activism in the United States. The most famous text of the men's movement, Robert Bly's Iron John, was not published until 1990, but its techniques of inculcating masculine pride were being experimented with in the later 1970s and 80s on both sides of the Atlantic. Five Cram, for example, had visited a sweat lodge on 'an Indian reservation' during a visit to the US. In 1979, the Anti-Sexist Men's News reported a British men's workshop which had combined co-counselling techniques with rituals that attempted to evoke 'indigenous' cultures: 
It was very elemental, weavingly mysterious. [...] We were milling around with our eyes closed introducing ourselves to each other non-verbally as we bumped into each other; it was suggested we do it nude, but that seemed a bit premature. [...] Then Pete led us off into an ashanti I think it's called, a repeating verse that's very rousing and rhythmic and we tramped off all together in a long line to the [telegraph] pole, lifted it still singing mostly and brought it round to the front of the terrace, [...] After we'd moved the pole, one brother said how like an ancient men-bond it felt to have done that together. ${ }^{72}$

Iron John, as a text, was often criticised by British men, including Five, who regretted its anti-feminist overtones. It did, however, resonate with the growing repudiation of guilt within the men's movement. Andy Barrow, for example, commented: 'I found [Iron John] very important in what it said about men needing to have the capacity for intimacy, for what's popularly called 'emotional literacy' or whatever you like, but — but being in touch with the full range of their emotions, and being able to share that without feeling humiliated - or being humiliated. ${ }^{73}$ Guilt, then, was widely repudiated as a negative emotion that could provide neither the direct anti-sexist action nor the male bonding that different factions of the men's movement sought.

\section{Shame and unconscious emotions}

Were anti-sexist men right in identifying their feelings of guilt, and repudiating this emotion as paralysing and negative? This is not a question commonly posed by historians in relation to the emotions of their historical subjects. Taken at face value, anti-sexist men declared that they felt guilty, and sought to feel differently. But reading their oral history testimony more closely allows further probing of their feelings. Historian Barbara Rosenwein perceptively argues that emotions may not be transparent to their bearer: "Although we think we know when we are expressing our emotions "sincerely" and "spontaneously" - and when we are not-we largely fool ourselves. ${ }^{74}$ Rosenwein remains aware that "emotions are usually not the sort of thing which can be characterised as " true" or "false." They are somewhere in the middle.' But her intervention on misidentification is useful, and reminds historians of the need to be attentive to the non-verbal traces of emotions that may suggest alternative affects. Without making too strong a claim about the 'truth' of 
historical emotional experience, I will argue that many anti-sexist men experienced a powerful affect - that of shame - that they were not able or willing to name.

Jo Stanley's thoughtful summary of the literature on shame suggests that 'Shame is produced when we are being judged by an actual or internalised audience according to social norms established by others. ${ }^{75}$ Psychologists note that it is felt and performed through physical symptoms of turning away from the gaze of the other (the real or imagined source of disapproval), by blushing, and covering the face. Shame is associated, as psychologist Helen Lewis argues, with an imagery of looking, and a 'disordered gaze'. The ashamed person imagines him or herself through the eyes of others, and cannot sustain eye contact. ${ }^{76}$ These symptoms go with feelings of being passive and rejected: 'shame is an emotion of the worthless, the paralyzed, the ineffective. ${ }^{, 77}$ It is understood as a wordless emotion, which does not easily name itself, but is cashed out in deep physical responses. Cultural theorist Sally Munt has argued that 'the accumulation of [shame] experiences can deposit compelling traces within the psyche. ${ }^{78}$ Shame thus has the potential to shape behaviour and selfhood, and plays out over the long term.

These characteristics of shame resonate very closely with a collection of anecdotes that were recounted by men during oral history interviews in 2011-4 when asked to reflect on their relationship to feminism. Their narratives all involved problems of establishing gaze. Paul Atkinson, quoted above, derided a man who looked at the ground rather than at women, as an example of guilty politics. Atkinson's comments on gaze were just one of a remarkable cluster of anecdotes that related to problems of eye contact. Another man interviewed had participated in men's groups while at university in the early 1980s, and recounted his role in defending users of abortion clinics in California by a weekly picket. He displayed ambivalence about male participation in this feminist activism:

'As a man, I felt really embarrassed, I felt embarrassed to be there, ... and yet I felt it really important to protect their right to do that, but I just also felt that I couldn't even look at these women, I didn't want to, I didn't want to be there. ${ }^{79}$

Mark Long similarly found that when staffing a crèche at feminist events, 'One of the experiences of crèches is not having eye contact with any of the women. 'I'm not here, really.'... I felt much more secure with at least two children under my arms, um, but looking 
at the ground... ${ }^{80}$ A third man, Pete 6 , recounted his participation at the women's peace camp Greenham Common in startlingly similar terms:

'there was a whole school of feminism... that you kind of almost... almost didn't make eye contact with,... because... that's certainly at Greenham Common... I always found at those big events, at the big - you know, um, feminist events, I always felt uncomfortable... because I didn't know where to look... ${ }^{81}$

At moments of public, feminist commitment, these men found that they couldn't meet the eyes of activist women. Another man active in London anti-sexist groups, Misha Wolf, recalled:

'I remember once being on a tube and reading Spare Rib and a woman sitting next to me smiled at me, so I shut my eyes and I kept my eyes shut for the rest of my journey 'cos I just didn't know, I had no idea how to deal with that. ${ }^{82}$

Despite this moment of apparent solidarity through print culture with a feminist woman, Misha found it impossible to respond, perhaps fearing that any gesture of political solidarity would be misread as heterosexual interest.

The problematisation of gaze was not only recalled through anecdotes, but also emerged during the oral history interviews. Dave Baigent, interviewed by me in 2011, described how he 'never looked down' on women firefighters, during his years working in the Fire Service in the 1970s and 80s. This discussion generated uncertainty about his gaze in the interview. He commented: 'I don't know whether to look at you or look away, I'm not sure. I don't like looking away, it's not my way. ${ }^{83}$ Clearly, eye contact and gaze proved persistently disturbing for anti-sexist men when recalling their engagements with women and feminists.

\section{The male gaze}

Some of the uneasiness about gaze and eye contact which emerged amongst antisexist men may have been a response to their awareness of the feminist problematization of the 'male gaze', and its capacity for 'little rapes'. In 1972, art critic John Berger published the influential text Ways of Seeing. He argued that 'To look is an act of choice... To look actively constitutes the world, and is never a neutral act, but presents a worldview, a 'way of 
seeing', Berger saw the gaze as fundamentally gendered: 'A woman must continually watch herself. She is almost continually accompanied by her own image of herself... From earliest childhood she has been taught and persuaded to survey herself continually.' Female subjectivity was thus constituted by awareness of the gaze of the other. Berger concluded: 'Men look at women. Women watch themselves being looked at. This determines not only most relations between men and women but also the relation of women to themselves.' For Berger, then, the male gaze established women's submission, a process exemplified in European art. ${ }^{84}$ The work of feminist film theorist Laura Mulvey further developed this idea, in her 1975 'manifesto', Visual Pleasure and Narrative Cinema. Mulvey argued that women were objectified by being culturally presented as objects of a male gaze. Women were often complicit in this process, and deep features of feminine subjectivity were invested in being looked at rather than looking. ${ }^{85}$ The problematic nature of men looking at (depictions of) women became a widely discussed element of feminist theory. My first response to the anecdotes of 'disordered gaze' was therefore that the men interviewed had internalised this literature and woven it into their self-narratives. Berger was certainly being read by antisexist men such as Andrew Tolson, who opened his influential 1977 anti-sexist book The Limits of Masculinity with a discussion of Berger's work. ${ }^{86}$

However, a deeper emotion can also be read into these stories. The 'gaze aversion' that characterises shame resonates strongly with the anecdotes. The anti-sexist men interviewed very rarely mentioned shame - indeed, only Paul Smith, out of the 40 interviews conducted, referred to shame. Yet there is evidence in the gaze anecdotes that a complex emotional mix of guilt and shame was associated with men's responses to feminism and feminists. Anti-sexist men felt ashamed that they had oppressed women, benefited personally from patriarchy, and failed to challenge its norms. This shame had the potential to infuse not just personal relationships, but also an existential sense of what it was to be male. There seemed no way of being a man that did not involve sexist (and homophobic) acts or omissions.

Understanding the emotional work that shame does provides deeper historical insight into the dynamics of the men's movement. While guilt was a difficult emotion that was largely rejected by the men's movement in favour of more positive emotions that might build up men's self esteem, shame was an affect they failed even to acknowledge. Acknowledging the infusion of shame amongst anti-sexist men is not just a question of scholarly precision. 
Understanding emotions and affects more fully is key to understanding the successes and failures of 'new manhood' in response to feminism in late twentieth century Britain. The extensive literature on guilt and shame amongst developmental and social psychologists and social theorists argues that these related emotions have very different functions in behaviour. Shame is understood to be a negative and damaging emotion. It can be a powerful moral emotion, but not one productive of action or reparation. Instead, its tendency to envelop the entire self tends to produce bitterness, blaming and resentment. As Jo Stanley notes, 'after the initial affect we quickly marshal ways to minimise shame's toxicity. ${ }^{, 87}$ This tendency can help to explain the powerful impulses towards positive masculinity and talk of 'men's liberation' and 'father's rights' that characterised later phases of the men's movement. Shame was an unstable affect that was quickly transmuted into less difficult emotions.

In comparison, guilt can be differentiated as an emotion that can be productive of empathy and responsibility. Rather than offering a critique of the essential being of the individual, it can be limited to specific acts, for which reparation can feasibly be made. While some guilt may be 'unresolved' and damaging, it can also lead, as psychologists have argued, to 'giving up rights, performing actions that appear to be symbolic substitutes for making reparations, undoing a wrong, or making order out of disorder. ${ }^{88}$ In other words, these are exactly the kinds of actions that anti-sexist men wanted to perform in relation to women - to give up their power and undo patriarchal wrongs. Some men deliberately embraced this - as Mark Long commented, 'we were acting on grounds of principle, to do things we didn't want to do or feel equipped to do, but we knew we had to do, so it's quite an old fashioned idea of acting out of duty and obligation, [...] it was love and duty that brought us in, there was none of this 'oh, now I feel free and wonderful." 89 In contrast, shame impelled other anti-sexist men to seek alternative emotions of fellowship and positivity that proved hard to integrate with feminism.

\section{Emotional change}

The contending conscious and unconscious affects that men felt in relation to feminism made projects of 'feeling differently' problematic. There are clear limits to the extent to which emotions are consciously manipulable. Historians of emotions have examined attempts to change individual or collective emotions, providing illuminating histories of how black, lesbian, gay and disabled activists within civil rights movements 
sought to replace shame with pride, loving solidarity and righteous anger. ${ }^{90}$ Historians of totalitarianism have examined how regimes sponsored modes of emotional expression, intending to inculcate malleable or desirable feelings in their subject populations. ${ }^{91}$ Whether by dictat or through utopian desire for social change, there have been many moments when regimes, individuals or grassroots social movements rejected a set of feelings, and sought to replace them with new emotions. This process, however, has not always been straightforward; emotions have their own dynamics and cannot always be externally prescribed.

The constraint and repression felt by some men in the 1970s and 1980s can be understood as what William Reddy terms 'emotional suffering'. There was a powerful sense of personal diminishment and repression that seemed endemic to modern masculinities. Feminism had helped men to re-evaluate their social experiences, pointing to their loneliness, inarticulacy and personal pain. It had also inspired men to seek something better - to find 'emotional liberty'. ${ }^{92}$ This was not, of course, a significant aim of the women's liberation movement. But some men (and women) were hopeful that men might find more satisfying emotional lives while working for a more equitable gender order.

In practice, it proved enormously difficult to 'rescript' men's emotions. Owen Davies still felt nervous about confronting the emotions of others in his Brighton men's group, as well as what he called 'getting out of control myself.' Another participant, Graham Stevens, reflected that in men's group meetings, 'I've been stifled by fears about your reactions to me... 93 The culture of rhetorical aggression in leftist politics made it particularly hard for anti-sexist men who had previously been involved in leftwing or revolutionary politics to find a different political mode. ${ }^{94}$ Ian Adams pointed to the tendency amongst men to adopt the familiar rhetoric of the left even when they turned to feminist campaigns. For Adams, men still talked of aiming 'to smash sexism, to destroy capitalism, to fight fascism.' This political aggression was often carried over into intimate relationships. Adams derided the sexual libertinism that led men on the left to 'bulldoze our way into casual, liberated relationships.' Yet he could not find an alternative; writing in 1975, Adams was convinced that in abandoning political assertiveness he faced a 'nihilism or vacuum' that destroyed his ability to make friends, and 'threatens what close relationships I have. ${ }^{95}$ Men's groups continued to seek and provide alternative emotional communities across the 1980s, though the shame felt by anti-sexist men, in many cases, led men's groups to embrace a more 'positive' men's 
politics, or talk of 'men's emancipation'. Feminist women proved highly suspicious of any initiative that excluded them; men's groups as a means of building trust and love between men seemed to displace anti-sexism as a site for guilt and reparation. These strains led to a significant weakening of the organized anti-sexist men's movement by the early 1990s.

\section{Conclusions}

The reworking and scrutinising of emotions remained an urgent concern for antisexist men throughout the two decades or so during which their activism flourished; there was no overall resolution of what John Berger had called the "urgency and complexity of our feelings'. ${ }^{96}$ Some men did feel that they had made huge personal gains, finding emotional comfort and release through the men's movement, and adapting their emotional styles in some settings. They became more emotionally expressive and engaged with their children, with other men, and with women. But there was no overall transformation of British men's emotional cultures. While men were committed to feeling differently, there was no easy construction of new emotional communities amongst men. Emotions are not fully open to manipulation, and despite intentions to feel differently, emotional journeys of consciousness raising and activism did not always result in the desired result. Painful emotions such as shame proved to be particularly unstable and hard to assimilate.

Zoe Strimpel's recent discussion of heterosexual relationships undertaken by feminist women acknowledges the complexity of heterosex within the political environment of women's liberation. Nonetheless, Strimpel documents possibilities of love and commitment between (feminist) men and women, when viewed from a female perspective. The male perspective looks rather different. In practice, individual anti-sexist men were, on occasion, able to craft satisfying personal or sexual relationships with both men and women. But a much bleaker perspective emerges from the oral histories and movement texts, revealing many anti-sexist men struggling to find personal composure, or to trust other men with their feelings. As late as 1985, a London activist was still commentating that 'The trouble with us men is that we are usually so blocked off from listening to our feelings that it takes an enormous amount of adjustment getting in touch with them... We need to read our feelings

like we need to read a speedometer.' 97 The motor vehicle metaphor was perhaps a deliberate or ironic attempt to find a language of talking about emotions that would make sense to men. 
Masculinities did undergo change in this period but the anti-sexist 'new man' was not its predominant form. Instead, Britain saw a proliferation of alternative forms or icons of masculinity, many of which had little progressive content - the (new) lad, the football hooligan, the nerd or geek, the clone and the hipster. ${ }^{98}$

Methodologically, reading shame into experiences of anti-sexism poses challenges for historians. How appropriate is it to read unconscious affects into the anecdotes and embodied experiences of historical actors? This can seem a heavy handed form of intervention by a historian who does not have access to the lived experience of the past. However, in relation to emotions, these kinds of critical approaches that challenge the self-reporting of emotions may prove feasible and useful. Emotions are not always transparent to those experiencing them. They are given shape through dreams, fantasies, physical gestures or routines; they may not leave historical traces in their own right, but must sometimes be read into rituals, practices and forms of behaviour that don't necessarily reference or name them. Michael Roper's cogent case for historians to be more attentive to inner states and their psychological complexity envisages psychoanalysis as a primary means of exploring the psychic. ${ }^{99} \mathrm{~A}$ wider set of interdisciplinary influences may however also be helpful. Historians can usefully draw on the insights offered by psychology; cultural studies has also proved helpful to the arguments rehearsed here. ${ }^{100}$ Interdisciplinary work can help to historicise how we read interior states, and provides finer grained ways of understanding the emotional content of human experiences.

\footnotetext{
${ }^{1}$ Lucy Goodison, 'Falling in Love', Spare Rib, 136 (1983), p. 52-5

${ }^{2}$ Betsy Ettore, 'The 'Perks' of Male Power', in Scarlet Friedman and Elizabeth Sarah. On the Problem of Men: Two Feminist Conferences (London, 1982), p. 222

${ }^{3}$ See for example Alison Fell, Hard Feelings: Fiction and Poetry from 'Spare Rib' (London, 1980). The emotions of the women's liberation movement are explored in recent work by Jeska Rees, 'A Look Back at Anger: The Women's Liberation Movement in 1978', Women's
} 
History Review 19, no. 3 (2010); Zoe Strimpel 'Heterosexual Love in the British Women's Liberation Movement: reflections from the Sisterhood and After archive', Women's History Review (2016); Sarah Browne, The Women's Liberation Movement in Scotland (Manchester, 2014), pp. 50-60

${ }^{4}$ Paul Morrison, interview with the author, 29 March 2012, Unbecoming Men: interviews on masculinities and the women's movement, 1970-1991, British Library; henceforth UB ${ }^{5}$ Islington Men's Group, 'What is Sexism?', (1974\0, Sheila Rowbotham papers 7SHR, The Women's Library, London School of Economics, henceforth SR.

6 'Notes from a Men Against Sexism Group, Brighton... 14 months on', Anti-sexist Men's Newsletter, (Dec 1979-Jan 1980), no page numbers

${ }^{7}$ Nicholas Owen, 'Men and the 1970's British Women's Liberation Movement', Historical Journal 56 (2013). On the rationale for women-only spaces, see Sheila Rowbotham, 'Women's Liberation and the New Politics', Spokesman Pamphlet 17, (1971); Anna Davin, ‘The London Feminist History Group’, History Workshop Journal, 9 (1980).

${ }^{8}$ David Ratovitksy, Men and Greenham Common, (pamphlet, no place of publication, 1983). Helen Franks papers folder 2, NA448 The Women's Library, London School of Economics. ${ }^{9}$ Amanda Goldrick-Jones, 'Pessimism, Paralysis, and Possibility: Crisis-Points in Profeminism', Journal of Men's Studies 9 (2001)

${ }^{10}$ Hughes, Celia. 'Young Socialist Men in 1960s Britain: Subjectivity and Sociability', History Workshop Journal, 73 (2012), p. 171.

${ }^{11}$ Matt Cook, 'Gay Times': Identity, Locality, Memory and the Brixton Squats in 1970's London', Journal of Twentieth Century British History, 24 (2013); Lucy Robinson, Gay Men and the Left in Postwar Britain: how the personal got political (Manchester, 2007) 
${ }^{12}$ Jeff Goodwin, James M. Jasper, and Francesca Polletta, Passionate Politics: Emotions and Social Movements (Chicago, 2001); Celia Hughes, Young Lives on the Left: Sixties Activism and the Liberation of the Self (Manchester, 2015).

${ }^{13}$ Martin Francis, 'A Flight from Commitment? Domesticity, Adventure and the Masculine Imaginary in Britain after the Second World War', Gender \& History, 19 (2007), p. 173. Frank Mort also notes the lack of emotional spontaneity between men in the postwar period, 'Social and Symbolic Fathers and Sons in Postwar Britain', The Journal of British Studies 38, (1999). In contrast, Michael Roper found that men were emotionally comfortable with other men, though awkward with women. Roper, Masculinity and the British Organization Man since 1945 (Oxford, 1994), pp. 166-7.

${ }^{14}$ Owen, 'Men and the 1970's British Women's Liberation Movement'; Lucy Delap, 'Uneasy Solidarity: The British Men's Movement and Feminism', in Kristina Schultz (ed.) The Women's Liberation Movement: Impacts and Outcomes (Oxford, 2017).

${ }^{15}$ As Hilary Young notes of Scottish men, and James Hinton makes clear in his study of the post-1981 Mass Observers, there were persistent cultures of masculinity that did not register social or emotional change until the very end of the twentieth century; Young, 'Being a man', in Lynn Abrams and Callum G. Brown. A History of Everyday Life in Twentieth Century Scotland (Edinburgh, 2010); James Hinton, Seven Lives from Mass Observation: Britain in the Late Twentieth Century. (Oxford, 2016). On ‘wimp’ stereotypes, see Posy Simmonds Collection, Guardian News and Media Archive, London. For more sympathetic accounts see Rowena Chapman and Jonathan Rutherford, Male Order: Unwrapping Masculinity (London, 1988); Lynne Segal, Slow Motion: Changing Masculinities, Changing Men (London, 1990). ${ }^{16}$ Claire Langhamer, The English in Love: The Intimate Story of an Emotional Revolution (Oxford, 2013). See also Teri Chettiar, "“More Than a Contract”: The Emergence of a State- 
Supported Marriage Welfare Service and the Politics of Emotional Life in Post-1945 Britain', Journal of British Studies 55 (2016).

${ }^{17}$ Sara Connolly and Mary Gregory. 'Women and Work since 1970', in Ian Gazeley et al (eds), Work and Pay in 20th Century Britain, (Oxford, 2007); Pat Ayers, 'Work, culture and gender: the making of masculinities in post-war Liverpool', Labour History Review, 69 (2004).

${ }^{18}$ Joyce Brothers 'Man - you're just driving her crazy', Daily Express, 7 Nov 1972, p. 5-6. Thomas Dixon has traced similar tentative shifts in the Daily Mirror over the 1970s, and more generally in popular culture and experimental therapies in the 1980s. Thomas Dixon, Weeping Britannia: A Portrait of a Nation in Tears (Oxford, 2015), pp. 267-73. On cohabitation, see Rebecca Probert, Cohabitation and Non-Marital Births in England and Wales, 1600-2012 (Basingstoke, 2014).

${ }^{19}$ Sean Nixon, Hard Looks: Masculinities, Spectatorship and Contemporary Consumption. (London, 1996). Frank Mort, Cultures of Consumption: Masculinities and Social Space in Late Twentieth Century Britain (London, 1996).

${ }^{20}$ Ute Frevert historically locates the terminology of affect and emotion, but argues that conceptually there is no clear difference between the 'basic emotions' or drives that might be named affect, and the so-called 'higher' mental emotions. This article uses affect as a heuristic device, to indicate a less conscious form of emotion, but without implying that the two can be definitively separated, or that some emotions should be understood as disembodied. Frevert, 'Defining Emotions: concepts and debates over three centuries', in Monique Scheer et al. (eds.), Emotional Lexicons: Continuity and Change in the Vocabulary of Feeling 1700-2000 (Oxford, 2014).

${ }^{21}$ Michael Roper, 'The Unconscious Work of History', Cultural and Social History, 11, 2, 2014, pp. 169-193; Michael Roper, 'Slipping out of View: Subjectivity and Emotion in 
Gender History', History Workshop Journal 59 (2005). Sally Alexander and Barbara Taylor, History and Psyche: Culture, Psychoanalysis, and the Past (Basingstoke, 2012).

22 Jan Plamper, The History of Emotions: An Introduction (Oxford, 2015); Benno Gammerl, 'Emotional Styles - Concepts and Challenges', Rethinking History 16 (2012).

${ }^{23}$ Monique Scheer, 'Are Emotions a Kind of Practice (and Is That What Makes Them Have a History)? A Bourdieuian Approach to Understanding Emotion', History and Theory, 51 (2012).

${ }^{24}$ Julie Marie Strange, "'She cried a very little": Death, grief and mourning in working-class culture, c. 1880-1914', Social History, 27 (2002), p. 161. Additional reflections from Barbara Rosenwein, Jan Plamper, William Reddy and Eugenia Lean on the bodily performance of emotions as elements of the labour of 'emotional self shaping' are found within the American Historical Review Conversation, 117 (2012). Paul Connerton explores a similar set of issues in his discussion of the somatic and choreographed elements of individual and social memory. Paul Connerton, How Societies Remember (Cambridge, 1989), pp. 72-4, 79-81. See also Willemijn Ruberga, 'Interdisciplinarity and the History of Emotions', Cultural and Social History, 6 (2009), p. 510 and Deborah Gould, Moving Politics: Emotion and ACT Up's fight against AIDS (Chicago, 2009). Anne Schmidt traces the longer history of how emotions might be figured in bodily gestures and facial expressions, drawing on Darwin's influential The Expression of Emotions in Man and Animals (London, 1872) and its precursors, to historicise attempts to elucidate the link between inner affect and physical embodiment. Schmidt, 'Showing Emotion, Reading Emotion', in Scheer et al., Emotional Lexicons.

${ }^{25}$ Laura Gowing, 'The manner of submission: gender and demeanour in 17 th century London' 2013, Cultural and Social History, p. 16, 33

${ }^{26}$ Mark Long, interview with the author, June 30 2012, UB 
${ }^{27}$ Paul Smith, interview with the author, June 30 2012, UB. On Big Flame and men's politics, see https://bigflameuk.wordpress.com/tag/mens-politics/ [accessed 14 July 2016] ${ }^{28}$ Hochschild, Arlie Russell, The Managed Heart: Commercialization of Human Feeling (Berkeley, 1983). Jill Nicholls, 'Smile...Or You're Sacked', Spare Rib 48, (1976), p.19 ${ }^{29}$ Jan Bradshaw, 'Now what are they up to? Men in the 'men's movement'!', in Friedman and Sarah. On the Problem of Men, p. 176

${ }^{30}$ Sheila Ernst and Lucy Goodison, In Our Own Hands: A Book of Self-Help Therapy. (London, 1981), p. 5

${ }^{31}$ Men Against Sexism, Islington Men's Group, 1974, 7shr/e/1 Folder 1, box 9, SR.

${ }^{32}$ Ian Adams, 7SHR/E/2 Box 9, SR

${ }^{33}$ Paul Smith, interview, UB

${ }^{34}$ Manchester Men Against Sexism Groups, c. 1976, emphasis in the original, 7shr/e/1 Folder 1 , box $9, \mathrm{SR}$

35 'Why a Men's movement?', Big Flame, May 1979, p. 15

${ }^{36}$ Les Garner, ‘A Men’s Movement?', Men's News, 5 Feb 1977. Idem., Stepping Stones to Women's Liberty; Feminist Ideas in the Women's Suffrage Movement 1900-1918, (London, 1984).

${ }^{37}$ Achilles Heel [henceforth AH] 1, summer 1978, p. 6-7

${ }^{38}$ The best known group was Red Therapy, a mixed sex group described in Ernst and Goodison, In Our Own Hands, Red Therapy (London, 1978) and John Rowan, 'Achilles Heel and the Anti-Sexist Men's Movement', Psychotherapy and Politics International 3, (2005). See also Mathew Thomson, Psychological Subjects: Identity, Culture, and Health in Twentieth-Century Britain (Oxford, 2006), pp. 257-86; Frank Furedi, Therapy Culture: Cultivating Vulnerability in an Uncertain Age (London, 2003), pp. 33-7

${ }^{39}$ Danny Cohen, 'Insights, Actions and Friendships', ASMN undated, c. 1981 p. 15 
${ }^{40}$ Jeff Hearn, Interview with the author, 22 Feb 2012, UB

${ }^{41}$ Rosie Brennan, ‘Women's Liberation Workshop for Women and Men’, Men's Magazine, 5 (1981), p. 7; Men's Magazine, 5 (1981), 'Pride in my Penis', p. 17

${ }^{42}$ Mark Long, Paul Smith, interviews, UB

${ }^{43}$ Tom Weld, 'Men's Week at Laurieston Hall', AH 2 1979, pp. 30-31.

${ }^{44}$ Keith Motherson 'Pressure to grow', MAN: Men's Anti-Sexist Newsletter [henceforth MAN], 16 (Winter 1981/2), p. 10

45 Thomas Dixon argues that the 1970s saw greater male expressiveness, though for most men, this was through conventional 'masculine' realms such as support for sports teams.

Dixon, Weeping Britannia, ch. 18

${ }^{46}$ Five Cram, interview with the author, 29 September 2012, UB

${ }^{47}$ Adrian Matthews, interview with the author, 11 January 2013, UB

${ }^{48}$ Laura King, Family Men: Fatherhood and Masculinity in Britain, 1914-1960 (Oxford, 2014).

${ }^{49}$ AH 2, 1979, p. 5

${ }^{50}$ Paul Smith, interview, UB

${ }^{51}$ AH 3, undated (c.1980), p. 5

52 'John Taylor', interview with the author, 29 March 2012; Mick Peper, Anti-Sexist Men's News [henceforth ASMN], Dec 1979-Jan 1980

${ }^{53}$ David Widgery, 'Sexual Politics', transcript of address to Woman's Voice meeting, Deptford, July 1977, Papers of David Widgery 799/15 Modern Records Centre, University of Warwick. See also Robinson, Gay Men and the Left, p. 100-102 on IS's troubled engagement with gay, lesbian and feminist politics.

${ }^{54}$ Neil, 'How we felt', Please can I stop being a tree soon? (London, n.d.), p. 21

${ }^{55}$ Mark Long interview, UB 
${ }^{56}$ Paul Morrison, Pregnant Fatherhood (London, 1977)

${ }^{57}$ Paul Atkinson, interview with the author, 23 March 2012, UB

${ }^{58}$ Phil Gross 'Forgetting myself. Feelings about Fatherhood', ASMN, Dec 1979-Jan 1980

${ }^{59}$ Atkinson, interview with the author, March 23 2012, UB

${ }^{60}$ Chris Heaume, interview with the author 10 May 2012, UB

61 'Nick Snow', interview with the author 27 May 2012, UB

62 'Andy Barrow', interview with the author, 8 May 2012 ; 'Dan Arras', interview with the author, 10 July 2012, UB. FNF was repudiated by others within the men's movement (see for example, 'Deciding Custody - one response', Low Plains Drifter: Leeds and Bradford Men's Anti-sexist Newsletter, no 8, Summer 1984, p. 11). The local group founded by Arras was fairly disconnected from the national FNF campaigners, and its publicity complained: 'Frankly, we find it extraordinary that we do not receive even minimal information from the national office.' (FNF Cambridge Branch Newsletter July 1993, no page numbers). But the branch's isolation allowed them to adopt a pro-feminist commitment to equal parenting and thus to see FNF organising as in keeping with anti-sexist politics.

${ }^{63}$ ONS Statistical Bulletin, Divorces in England and Wales, 2010, http://webarchive.nationalarchives.gov.uk/20160105160709/http://www.ons.gov.uk/ons/dcp1 71778_246403.pdf accessed 9 March 2016.

${ }^{64}$ Paul Wolf-Light 'Apart from the Children', Body Politic, 2 (1992), pp. 40-1

${ }^{65}$ Atkinson, interview with the author, UB

${ }^{66} \mathrm{AH}, 1$ (1978), p. 7

${ }^{67}$ Atkinson, interview with the author, UB

${ }^{68}$ Peter Martin, 'Acting Away from Guilt', MAN, 16 (Winter 1981/2) p. 17

${ }^{69}$ Bill Bachle, MAN, 16 (Winter 1981/2) p. 16; 'Letter from Sarah', MAN, 14, (Jan/Feb 1981), p. 6-7. See also Jan Bradshaw, 'Now what are they up to?' p. 177-9 
${ }^{70}$ Peter Martin, 'Acting Away from Guilt', p. 17

${ }^{71}$ Five Cram, ‘Anti-Sexism: What?' Against Sexism Against Patriarchy-ASAP: A Profeminist newsletter for People in London, 8 (1982), p. 12

${ }^{72}$ Robert Bly, Iron John: A Book About Men. (Reading, Mass., 1990). Five Cram, ASMN, 7, (1979), no page numbers

${ }^{73}$ Barrow, interview with the author. On 'men's liberation', see also John Walton, Men's News, 5 Feb 1977, no page numbers; Steve Mason, 'Loving Me(n)', MAN, 23 (1986), p. 4-5

${ }^{74}$ Barbara Rosenwein, 'The Historical Study of Emotions', American Historical Review, 117 (2012), p. 1496

${ }^{75}$ Jo Stanley, 'We were skivvies/we had a ball': Shame and interwar ships' Oral History, 38 (2010), pp. 64-74.

${ }^{76}$ Helen Lewis, Shame and Guilt in Neurosis (New York, 1971). See also M. Mascolo and Kurt Fischer, 'Developmental transformations in appraisals for pride, shame, and guilt', in June Price Tangney and Kurt W. Fischer (eds), Self-Conscious Emotions: The Psychology of Shame, Guilt, Embarrassment, and Pride (London, 1995), p. 64-113, p. 68

${ }^{77}$ Sara Ahmed, The Cultural Politics of Emotion (Edinburgh, 2004); June Price Tangney and Ronda L Dearing, Shame and Guilt (New York, 2002), p. 93

${ }^{78}$ Sally Munt, Queer Attachments: The Cultural Politics of Shame (Aldershot, 2007).

79 'Sam Hilton', Interview with the author, March 28 2012, UB

${ }^{80}$ Long, interview with the author, UB

81 'Pete 6', interview with the author, 29 September 2012, UB

${ }^{82}$ Wolf, Interview with the author, 31 May 2012 and 3 July 2012, UB

${ }^{83}$ Dave Baigent, Interview with the author, 10 Dec 2011, UB

${ }^{84}$ John Berger, Ways of Seeing (Harmondsworth, 1972), pp. 8, 46, 47

${ }^{85}$ Laura Mulvey, 'Visual Pleasure and Narrative Cinema', Screen, (1975) 
${ }^{86}$ Andrew Tolson, The Limits of Masculinity (London, 1977).

${ }^{87}$ Stanley, 'Shame and interwar ships', p. 71

${ }^{88}$ J. Lindsay-Harz, J. De Rivera and M. Mascolo, 'Differentiating guilt and shame and their effects on motivation', in Tangney, Price and Fischer, Self-Conscious Emotions, p. 289

${ }^{89}$ Long, interview with the author, UB

${ }^{90}$ See for example Jessica Gienow-Hecht, Emotions in American History: an international assessment (New York, 2010); Fred Pelka, What have we done? An oral history of the disability rights movement (Amherst, 2012).

${ }^{91}$ See for example Jonathan Waterlow, 'Sanctioning laughter in Stalin's Soviet Union', History Workshop Journal 79 (2015).

${ }^{92}$ William M. Reddy, The Navigation of Feeling: A Framework for the History of Emotions (Cambridge, 2001).

93 'Notes from a Men Against Sexism Group, Brighton', no page numbers

${ }^{94}$ Celia Hughes, 'Young Socialist Men in 1960s Britain : Subjectivity and Sociability', History Workshop Journal, 73 (2012), pp. 170-192

${ }^{95}$ Paper presented at Brighton Men Against Sexism conference, March 1975, 7SHR/E/2 Box $9, \mathrm{SR}$

${ }^{96}$ Berger, Ways of Seeing, p. 59

${ }^{97}$ Gerry Popplestone. 'Are we really changing?' MAN, Spring (1985) p. 16-7

${ }^{98}$ Mort, Cultures of Consumption; Sean Nixon, 'Resignifying Masculinity: From 'New Man' to 'New Lad', in David Morley and Kevin Robins, (eds), British cultural studies: geography, nationality, and identity (Oxford, 2001), pp. 373-385; Momin Rahman, 'David Beckham as a Historical Moment in the Representation of Masculinity', Labour History Review, 69 (2004); Matt Cook, A Gay History of Britain : Love and Sex between Men since the Middle Ages (Oxford, 2007), p. 188-9. 
${ }^{99}$ Roper, 'The Unconscious Work of History.'

${ }^{100}$ Ruberg, 'Interdisciplinary and the History of Emotions' 